\title{
Front Matter: Volume 9839
}

, "Front Matter: Volume 9839," Proc. SPIE 9839, Degraded Visual Environments: Enhanced, Synthetic, and External Vision Solutions 2016, 983901 (27 June 2016); doi: 10.1117/12.2245784

SPIE. Event: SPIE Defense + Security, 2016, Baltimore, MD, United States 


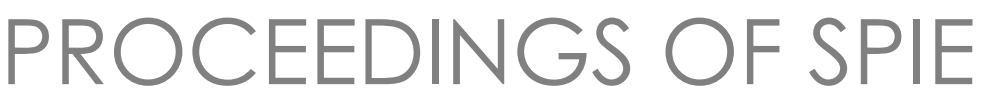

\title{
Degraded Visual Environments: Enhanced, Synthetic, and External Vision Solutions 2016
}

\author{
Jack Sanders-Reed \\ Jarvis J. Arthur III \\ Editors
}

19-20 April 2016

Baltimore, Maryland, United States

Sponsored and Published by

SPIE 
The papers in this volume were part of the technical conference cited on the cover and title page. Papers were selected and subject to review by the editors and conference program committee. Some conference presentations may not be available for publication. Additional papers and presentation recordings may be available online in the SPIE Digital Library at SPIEDigitallibrary.org.

The papers reflect the work and thoughts of the authors and are published herein as submitted. The publisher is not responsible for the validity of the information or for any outcomes resulting from reliance thereon.

Please use the following format to cite material from these proceedings:

Author(s), "Title of Paper," in Degraded Visual Environments: Enhanced, Synthetic, and External Vision Solutions 2016, edited by Jack Sanders-Reed, Jarvis J. Arthur III, Proceedings of SPIE Vol. 9839 (SPIE, Bellingham, WA, 2016) Six-digit Article CID Number.

ISSN: 0277-786X

ISSN: 1996-756X (electronic)

ISBN: 9781510600805

Published by

SPIE

P.O. Box 10, Bellingham, Washington 98227-0010 USA

Telephone +1 3606763290 (Pacific Time) · Fax +1 3606471445

SPIE.org

Copyright @ 2016 , Society of Photo-Optical Instrumentation Engineers.

Copying of material in this book for internal or personal use, or for the internal or personal use of specific clients, beyond the fair use provisions granted by the U.S. Copyright Law is authorized by SPIE subject to payment of copying fees. The Transactional Reporting Service base fee for this volume is $\$ 18.00$ per article (or portion thereof), which should be paid directly to the Copyright Clearance Center (CCC), 222 Rosewood Drive, Danvers, MA 01923. Payment may also be made electronically through CCC Online at copyright.com. Other copying for republication, resale, advertising or promotion, or any form of systematic or multiple reproduction of any material in this book is prohibited except with permission in writing from the publisher. The CCC fee code is 0277-786X/16/\$18.00.

Printed in the United States of America.

Publication of record for individual papers is online in the SPIE Digital Library.

\section{SPIE. DIGITAL}

SPIEDigitalLibrary.org

Paper Numbering: Proceedings of SPIE follow an e-First publication model, with papers published first online and then in print. Papers are published as they are submitted and meet publication criteria. A unique citation identifier (CID) number is assigned to each article at the time of the first publication. Utilization of CIDs allows articles to be fully citable as soon as they are published online, and connects the same identifier to all online, print, and electronic versions of the publication. SPIE uses a six-digit CID article numbering system in which:

- The first four digits correspond to the SPIE volume number.

- The last two digits indicate publication order within the volume using a Base 36 numbering

system employing both numerals and letters. These two-number sets start with 00, 01, 02, 03, 04 , $05,06,07,08,09,0 A, 0 B \ldots 0$, followed by 10-1Z, 20-2Z, etc.

The CID Number appears on each page of the manuscript. The complete citation is used on the first page, and an abbreviated version on subsequent pages. 


\title{
Contents
}

\author{
$\checkmark$ Authors \\ vii Conference Committee
}

\section{SESSION 1 SYSTEM PERFORMANCE EVALUATION}

983902 Flight test results of helicopter approaches with trajectory guidance based on in-flight acquired LIDAR data [9839-2]

983904 Toward autonomous rotorcraft flight in degraded visual environments: experiments and lessons learned [9839-4]

983905 Capability comparison of pilot assistance systems based solely on terrain databases versus sensor DB fused data systems [9839-5]

983906 Performance evaluation of active sub-Terahertz systems in Degraded Visual Environments (DVE) [9839-6]

\section{SESSION 2 SYMBOLOGY AND SYNTHETIC VISION}

983907 The glass dome: low-occlusion obstacle symbols for conformal displays [9839-7]

983908 Amplifying the helicopter drift in a conformal HMD [9839-9]

983909 A concept for a virtual flight deck shown on an HMD [9839-10]

9839 OA Helmet mounted display supporting helicopter missions during en route flight and landing [9839-11]

\section{SESSION 3 ADVANCED VISION SYSTEMS FOR COMMERCIAL FLIGHT}

$9839 \mathrm{OB}$ Present and future of vision systems technologies in commercial flight operations (Invited Paper) [9839-12]

\section{SESSION 4 HUMAN PERFORMANCE EVALUATION}

9839 OC Assessing impact of dual sensor enhanced flight vision systems on departure performance [9839-13]

9839 OD Measuring the denoising performance of the human visual system for optimum display quality [9839-14] 
9839 OE Perceptual issues for color helmet-mounted displays: luminance and color contrast requirements [9839-15]

\section{SESSION 5 IMAGE PROCESSING AND DISPLAY}

9839 OF Wavelet based image visibility enhancement of IR images [9839-16]

9839 OG A new optical system for low-profile HUD by using a prism waveguide [9839-17]

$9839 \mathrm{OH} \quad$ Global vision systems regulatory and standard setting activities [9839-18]

\section{SESSION $6 \quad$ ADVANCED DVE SENSING}

9839 Ol Characterization of the OPAL LiDAR under controlled obscurant conditions [9839-19]

9839 0J Three-dimensional landing zone ladar [9839-20]

9839 OL Mapping of ice, snow and water using aircraft-mounted LiDAR [9839-22]

9839 ON Display of real-time 3D sensor data in a DVE system [9839-24]

\section{SESSION 7 DISPLAY ADVANCES, APPLICATIONS, AND FUTURE DESIGN}

9839 OP Cooling of organic light-emitting diode display panels with heat pipes [9839-26]

\section{SESSION 9 HEAD-UP AND BODY-WORN DISPLAYS}

9839 OV Combatant eye protection: an introduction to the blue light hazard [9839-31]

9839 OW Head-up, eyes-out in day and at night: Striker HMD, evolution or revolution? [9839-32] 


\section{Authors}

Numbers in the index correspond to the last two digits of the six-digit citation identifier (CID) article numbering system used in Proceedings of SPIE. The first four digits reflect the volume number. Base 36 numbering is employed for the last two digits and indicates the order of articles within the volume. Numbers start with 00, 01, 02, 03, 04, 05, 06, 07, 08, 09, 0A, OB...0Z, followed by 10-1Z, 20-2Z, etc.

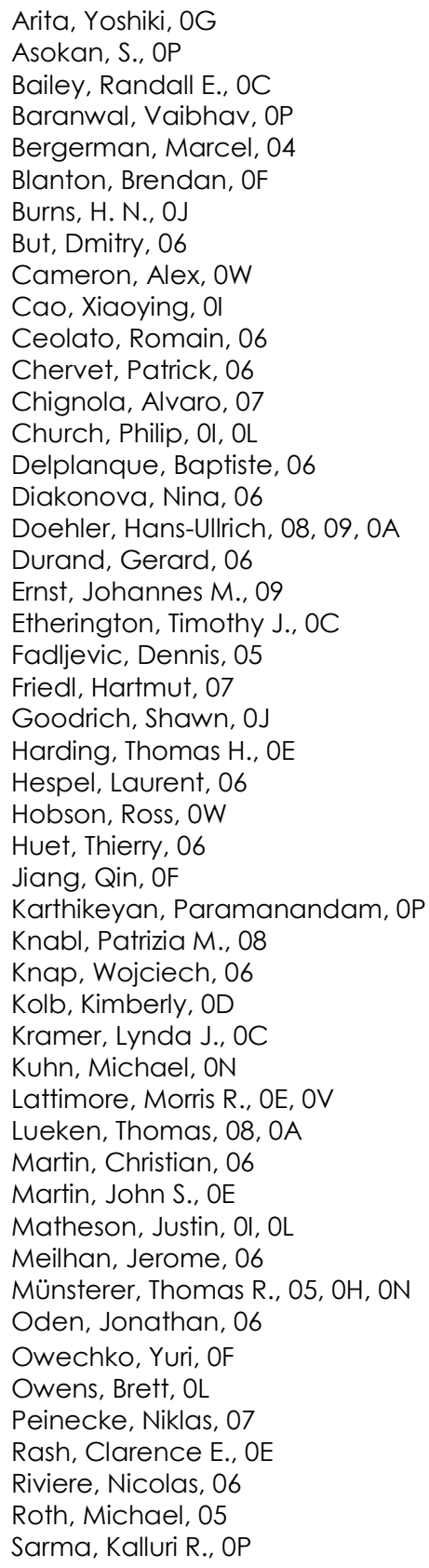

Savage, James, OJ

Scheuch, Jürgen, 05

Schmerwitz, Sven, 08, 09, 0A

Schmid, Daniela, 07

Severance, Kurt, OC

Simoens, François, 06

Singh, Sanjiv, 04

Spiker, Spencer, 04

Stambler, Adam, 04

Statz, Jonathan, OE

Strobel, Michael, 05, 0N

Sure, Anita, OP

Tanaka, Masato, OG

Tanguy, Bernard, 06

Tiana, Carlo, $\mathrm{OH}$

Vankayala, Gowtham Kumar, OP

Völschow, Philipp, 05, 0N

Ward, Jim, OB

Zimmermann, M., 02 
Proc. of SPIE Vol. $9839983901-6$

Downloaded From: https://www.spiedigitallibrary.org/conference-proceedings-of-spie on 26 Apr 2023 Terms of Use: https://www.spiedigitallibrary.org/terms-of-use 


\section{Conference Committee}

Symposium Chair

David Logan, BAE Systems (United States)

Symposium Co-chair

Donald A. Reago Jr., U.S. Army Night Vision \& Electronic Sensors Directorate (United States)

Conference Chairs

Jack Sanders-Reed, The Boeing Company (United States)

Jarvis J. Arthur III, NASA Langley Research Center (United States)

Conference Program Committee

Daniel D. Desjardins, Air Force Research Laboratory (United States)

Thomas R. Muensterer, Cassidian (Germany)

Niklas Peinecke, Deutsches Zentrum für Luft- und Raumfahrt e.V. (Germany)

Carlo L. Tiana, Rockwell Collins, Inc. (United States)

Session Chairs

1 System Performance Evaluation

John N. Sanders-Reed, The Boeing Company (United States)

2 Symbology and Synthetic Vision

Thomas R. Muensterer, Airbus Defence and Space (Germany)

3 Advanced Vision Systems for Commercial Flight

Jarvis J. Arthur III, NASA Langley Research Center (United States)

4 Human Performance Evaluation

Jarvis J. Arthur III, NASA Langley Research Center (United States)

5 Image Processing and Display

Carlo L. Tiana, Rockwell Collins, Inc. (United States)

6 Advanced DVE Sensing

Niklas Peinecke, Deutsches Zentrum für Luft- und Raumfahrt e.V. (Germany) 
7 Display Advances, Applications, and Future Design Jim Metzer, Thales Visionix, Inc. (United States)

8 Color Difference and Color Detail

Kalluri R. Sarma, Honeywell Technology (United States)

$9 \quad$ Head-up and Body-worn Displays

Gary W. Jones, NanoQuantum Sciences, Inc. (United States) 